\author{
KRISTÝNA FALÁTKOVÁ, MIROSLAV ŠOBR, \\ JAN KOCUM, BOHUMÍR JANSKÝ
}

\title{
HYDROLOGICAL REGIME OF ADYGINE LAKE, TIEN SHAN, KYRGYZSTAN
}

\begin{abstract}
FALÁTKOVÁ, K., ŠOBR, M., KOCUM, J., JANSKÝ, B. (2014): Hydrological regime of Adygine lake, Tien Shan, Kyrgyzstan. Geografie, 119, No. 4, pp. 320-341. - This article provides a detailed analysis of the hydrological regime of the Adygine glacial lake in Tien Shan, Kyrgyzstan, and of the specific factors which affect it. Glaciers of central Tien Shan are considered to be very sensitive indicators of climate change. The studied lake belongs to a system of relatively recently formed lakes situated near the front of the retreating glacier and is numbered amongst the potentially dangerous. The lake's water level and its dependence on the development of climatic conditions in the area were monitored in detail in 2007-2012. A substantial part of this paper is the evaluation of the inflow and outflow balance of the lake's basin. The results confirmed that the hydrological regime is glacial and exhibits its typical characteristics, such as a seasonal evolution of runoff delay or significant diurnal fluctuation of the lake's water level. During the monitored period, no major changes in annual lake level fluctuation were recorded.
\end{abstract}

KEY WORDS: hydrological regime - glacial lake - glacier melt - water level fluctuation surface outflow - hydrological balance.

Created with support of GA UK project No. 619112 "Risk analysis of glacial outburst lakes in Adygine area (Tien Shan Mts, Kyrgyzstan)", NATO CLG Project "Glacier hazards in Kyrgyzstan: implications for resource development and water security in Central Asia” and project of specific university research No. 3300-244-267 202 1. Outputs of Czech development cooperation project 194/07-09/MŽP/B (RP/9/2007) "Analysis of the risk of failure of alpine lake dams and the mitigation of the consequent impacts; Kyrgyz Republic" were also used in this article.

\section{Introduction}

Climatic changes and their manifestation currently represent one of the main topics of hydrology (Aizen et al. 1997; Dvořák, Hladný, Kašpárek 1997; Nijssen et al. 2001; Middelkoop et al. 2001; Bates et al., eds. 2008). Glaciers in high mountain regions of the world are considered very sensitive indicators of climatic change (Beniston, Diaz, Bradley 1997; Li et al. 2007; Hagg et al. 2007; Zhou, Jing, Zhao et al. 2010; Janský et al. 2011). These areas include also the northern part of the Tien Shan mountain range (Gao et al. 2010). Development of glacial lakes within Kyrgyz range is monitored in detail since 2004 (Černý et al. 2010). The rapid retreat of glaciers causes extreme increase in meltwater flows in the summer periods, which leads to overfilling of lake basins and destabilization of their moraine dams (Ageta et al. 2000). These processes result in frequent outbursts of glacial lakes (Clague, Evans 2000; Kattelmann 2003). The studied lake is a part of a lake system and is a very suitable research 
subject. At this site there is a risk of outbursts and subsequent development of floods or mudflows threatening Ala Archa Valley, which is very popular with tourists and is directed towards Bishkek, the capital of Kyrgyzstan.

Adygine Lake is a relatively young glacial lake (began to develop in 1960's) dammed by a rock step which is covered by moraine material with buried ice (Černý et al. 2010). This type of dam is very frequent in high mountain areas (Janský, Šobr, Yerokhin 2006) and is relatively vulnerable in terms of its stability and given its subsurface outflow paths. The danger then lies in the fact that Adygine Lake is part of an entire system of dynamically forming and developing lake basins.

The aim of this paper is to evaluate the hydrological regime of the largest lake of the site - Adygine Lake - based on climatic and hydrological measurements. The results presented here could be used in the context of further procedures associated with modelling of possible lake outburst scenarios, or with installation of a warning system for Bishkek. The results of the work are compared with relevant literature focusing on similar topics.

\section{Glacial Hydrological Regime}

Lakes with glacier meltwater inflow show a similar annual and diurnal cycle of water level fluctuations as glacial streams. Changes in water volume of water in the lake are caused by changes in the hydrological balance, especially the inflow. The highest water levels correlate with periods of highest water inflow, which usually occurs in July and August. The hydrological regime of the lake inflow is influenced by climatic conditions in the lake catchment. Thanks to the retention capacity of the lake, however, changes in the water level are considerably smoother than in rivers (Singh, Singh 2001).

Inflow into a lake is composed of four main sources, the importance and influence of them changes throughout the year. These are the base flow, snowmelt, glacier melt and atmospheric precipitation (Singh, Singh 2001). Base flow has multiple sources, which are described in detail by Röthlisberger and Lang (1987). One of them is the runoff resulting from melting on the glacier base. Melting of ice occurs due to friction and energy exchange between the glacier and its bedrock. Other sources can include gradually released water retained in glacial cavities, meltwater leaking through the snow or firn or groundwater. Base flow is a relatively constant source of water for the lake throughout the year. It is virtually the only source in winter and its share of the total inflow decreases distinctly in summer.

Another source is water from melting snow. In the studied area, snow begins to melt in April-May and continues until June, sometimes July. Due to the high albedo of a new snow, melting is not as intensive as in the case of glacier ice and the retention capacity of the snow cover slows the meltwater runoff even further (Singh, Singh 2001). This results in a relatively balanced inflow from snow melt with rather smaller diurnal fluctuations, which reaches the lake with a certain delay.

Inflow from glacier surface melting is the main source of water during the summer period. Glacial ice has lower albedo than snow, therefore it melts faster 
and, moreover, it does not have the same retention capacity as snow. However, meltwater may be retained in cracks and cavities in the glacier (Röthlisberger, Lang 1987). Therefore, water flows on the glacier surface as well as through moulins and channels inside the glacier (R-channels; Röthlisberger 1972) and then through channels incised into the bedrock or sediment (N-channels; Nye 1973). As summer season progresses, this drainage system is so developed that the meltwater from the glacier reaches the lake in a relatively short time. Thanks to the rapid response of the glacier to increased solar radiation and air temperature, a significant diurnal regime is developed for lakes and streams supplied from the glacier (Singh, Singh 2001). The water level maximum occurs several hours after sun culmination, then the inflow slowly declines to the minimum in the morning followed by a rapid increase (Röthlisberger, Lang 1987). The time lag therefore ranges from dozens of minutes to several hours (depending on the lake distance from the glacier front). However, shortening of this time during the ablation season (due to increasingly efficient system of drainage channels) is particularly important (Singh, Singh 2001).

The fourth source is water from precipitation that occurs mostly during summer at the studied site. Although the direct effect of precipitation on lake water level is usually not very important, its indirect effect is rather significant (Collins 1998). Warm liquid precipitation, especially in late summer, falling on the glacier surface accelerates its melting, and thus may cause a significant increase in runoff from the glacier while solid precipitation (snow) has a dampening effect, as it almost completely stops surface glacier melting and the daily glacial regime is replaced by a low base flow even for several days after the precipitation event (Hubbard, Glasser 2005).

Changes in the runoff volume from a glacier can be monitored at several time scales. Short-term daily and annual variability is caused by the variability of meteorological conditions. However, changes in runoff reflecting changes in mass balance of the glacier can be seen in the long term. Gradual air warming first leads to an increased runoff from the glacier, but later the runoff decreases due to a reduction of the glacier area (Benn, Evans 2010).

\section{Study Area}

The Adygine area is located in the higher eastern part of the Kyrgyz range which is also called Northern Tien Shan (Adyshev, ed. 1987, Koppes et al. 2008). The Adygine glacier complex (3,400-4,200 $\mathrm{m}$ a.s.l.) is located on the northern side of the Kyrgyz ridge about $40 \mathrm{~km}$ south of Bishkek. The study area is at the end of a tributary valley that joins the main Ala Archa valley from the west. Several genetic types of glacial lakes could be found in this area (Fig. 1): morainic-glacier lakes, thermokarst lakes or lakes dammed by a rock step. The Adygine Glacier as well as the majority of glaciers in Central Asia has been undergoing significant degradation since mid-1920s, which has even intensified in recent years (Dyurgerov 2003, Aizen et al. 2006, Unger-Shayesteh et al. 2013).

The retreat of the glacier front has resulted in formation of five small lakes in the adjacent depressions dammed by a hummocky moraine. Despite the low 
volume of retained water, these lakes are considered potentially dangerous due to their rapid development. The first signs of the lakes were reported in 2004 and a year after the largest of them (Lake 3) had a surface area of $5,700 \mathrm{~m}^{2}$ and a depth of $3.8 \mathrm{~m}$ (Černý et al. 2010). In 2012, the maximum depth of this lake was already $10.3 \mathrm{~m}$ and the surface area increased to $8,800 \mathrm{~m}^{2}$. The largest lake of this area, also called Upper Adygine Lake, is located lower and is dammed by a rock step (riegel) and partly also by a moraine with buried ice. There are two drainage paths from the lake: one on the surface over a considerably weathered rock outcrop and the second through subsurface channels. The entire complex is complemented by the Lower Adygine Lake supplied by the surface flow from the higher located Upper Adygine Lake. It is a thermo-

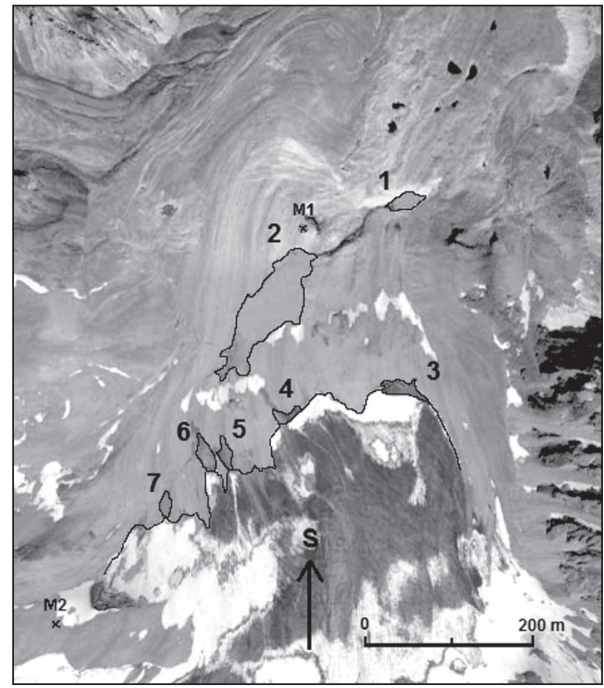

Fig. 1 - Satellite image of study area Adygine, 2006. 1 - Lower Adygine, 2 - Upper Adygine, 3-7 - present ice-contact lakes, M1, M2: meteorological stations. Source: Google Earth. karst lake without surface outflow with significant fluctuation in water level and volume of retained water during the day (between 10,000 and $15,000 \mathrm{~m}^{3}$ ), which is probably caused by the limited capacity of subsurface drainage routes (Janský, Šobr, Engel 2010).

The present study is focused mainly on the largest lake, which is further on refered to as "Adygine Lake".

The climate in the study area is continental. In winter it is affected mainly by the Siberian anticyclone that blocks the progress of air masses from the west and thus reduces the amount of winter precipitation in the region (Aizen, Aizen 1994). This is seen especially in the Ala Archa Valley. Total precipitation in winter is therefore very low (10-20 mm per month, Hagg et al. 2007).

Aizen, Aizen, Melack (1995) describe the distribution of precipitation in the mountains of Tien Shan during the year. The occurrence of one precipitation maximum in May-July is typical for mountainous regions of the northern hemisphere. At altitudes, where the Adygine area is situated, i.e. above 3,400 m a.s.l., summer precipitation represents according to Aizen, Aizen, Melack (1996) up to $72 \%$ of the annual amount, about $65 \%$ of this precipitation falls as snow. The precipitation minimum occurs in December and January when only 2-5\% of the annual precipitation falls on average (Aizen, Aizen, Melack 1996).

The annual variation in temperature in the lower part of the Ala Archa Valley $(2,200 \mathrm{~m}$ a.s.l. $)$ is shown in Figure 2. The temperatures drop to the lowest point in January (average temperature of $-9^{\circ} \mathrm{C}$ in $2002-2010$, minimum temperature goes down to $-25^{\circ} \mathrm{C}$ ) and the air temperatures culminate during July and August with average temperature of $13^{\circ} \mathrm{C}$ (Černý et al. 2010). About 1,500 metres higher in the Adygine area, the temperature cycle during the year 

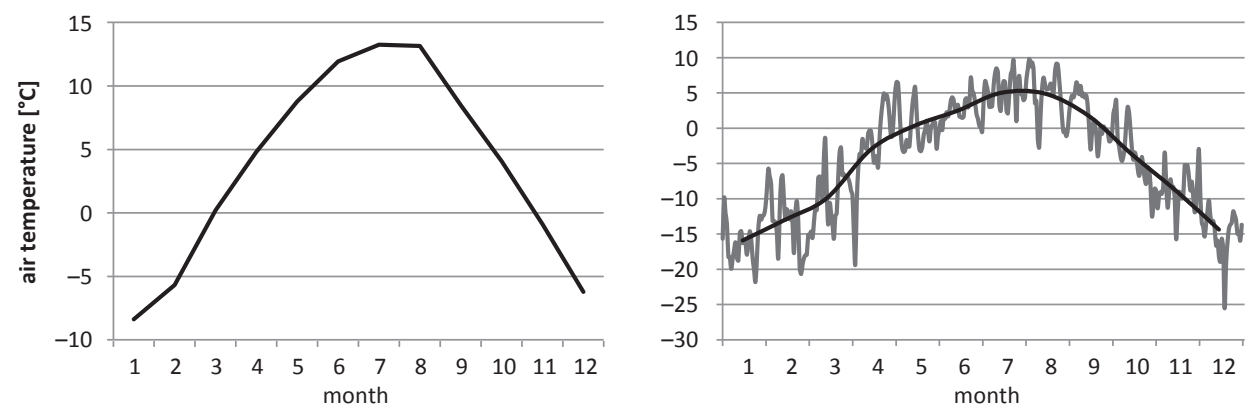

Fig. 2 - Mean monthly air temperature (left), meteorological station Ala Archa, 2,200 m a.s.l., 2002-2008 and mean monthly and daily air temperature (right), heat sensor at Adygine, 3,653 m a.s.l., 2011. Source: Černý et al. 2010.

is similar, however, the air temperatures are lower and the annual amplitude is smaller. The average temperature of the warmest month (August) is around $5^{\circ} \mathrm{C}$, in January the average temperature is mostly around -10 to $-15^{\circ} \mathrm{C}$ (Černý et al. 2010).

\section{Material and Methods}

\subsection{D a t a}

Background for research in Adygine area is provided by a research station, which was built near the outlet from Adygine Lake in 2008. Meteorological data are provided by two automatic meteorological stations, one of them is located at an altitude of 3,550 $\mathrm{m}$ ("lower") and the other one ("upper") is located at an altitude of 3,800 $\mathrm{m}$ a.s.l. To complement the temperature range from weather stations, data from a sensor located on the right side of the glacier basin at an altitude of 3,653 $\mathrm{m}$ a.s.l. were also used. Data from the national meterological station (2,200 m a.s.l.) located near the Ala Archa National Park were available for the description of atmospheric conditions in the lower part of the Ala Archa Valley.

Hydrological data are provided by a pressure sensor (water level indicator) which was installed in Adygine Lake in August 2007. From August 19, 2007 until July 24, 2013, only two outages were reported. Unfortunately they were both relatively long - the series is missing from July 31 till August 22, 2008 and from August 1 till August 17, 2011. A detailed bathymetric map based on measurements in 2008 (Černý et al. 2010) has been used to calculate the volume of the lake at various water levels.

\subsection{Methods}

Despite annual maintenance, continuous data series are not available from any of the meteorological stations, which is probably caused by low resistance 


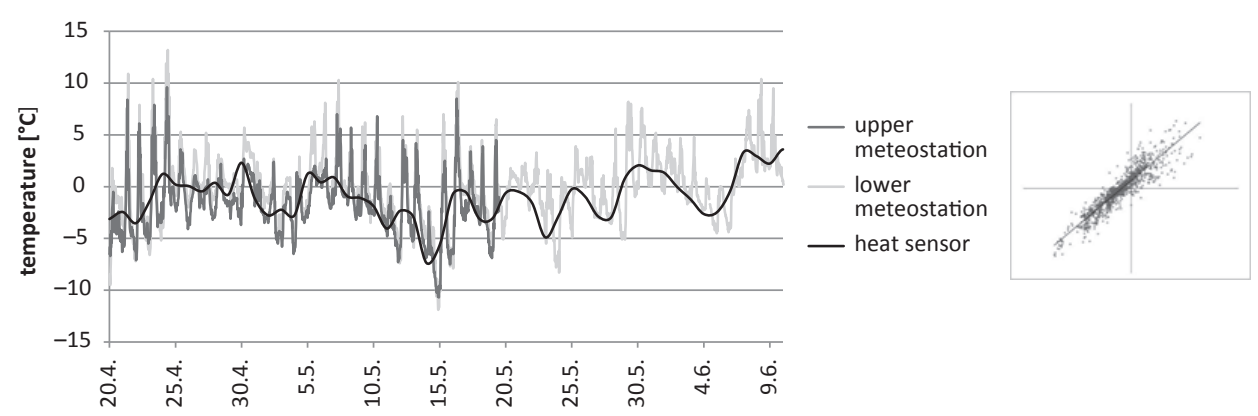

Fig. 3 - Air temperature fluctuations measured at upper meteorological station (left), lower meteorological station and mean daily air temperature measured by a heat sensor, 2010 and correlation graph of air temperature (right) from upper (axis x) and lower (axis y) meteorological station.

to weather conditions (strong wind, low temperatures) and mainly to static electricity effect during storms. Series from various sources were used for individual years due to lack of continuous data from a single station. The maximum altitude difference between the two meteorological stations is about $250 \mathrm{~m}$, therefore the measured temperatures differ, however, their time development is analogous (Fig. 3) - the correlation coefficient of the two monthly temperature series from the stations is 0.92 .

On July 26, 2008 at 7:30 a.m., the lake level was measured by total geodetic station at 3,542.966 $\mathrm{m}$ a.s.l. and this corresponded to $5,966 \mathrm{~m}$ at the level indicator. Therefore, a value of $3,537 \mathrm{~m}$ was added to all values measured by the level indicator to obtain information about the altitude of water levels.

The methodology used for the bathymetry measurements is described by Česák and Šobr (2005). This methodology was modified for use in high mountain areas and for research of glacial lakes.

Discharge at the outflow from Adygine Lake was measured using a hydrometric propeller OTT C2 and in accordance with ČSN ISO 748 on 19 verticals at an interval of $0.5 \mathrm{~m}$ (Fig. 4). The only exception was the measurement at the highest water level $(0.67 \mathrm{~m})$, where the width of the outflow was divided into 25 verticals at $0.5 \mathrm{~m}$. The measurements were taken from August 3 to August 5, 2012 at the same location at different water levels. During the measurement, the value on the water-level measuring pole located near the outlet was recorded, so that the corresponding altitude of the lake level could be assigned to the measured depths of the profiles. Therefore, it was necessary to identify the relationship between the values on the water-level measuring pole and on the level indicator: $0.47 \mathrm{~m}$ on the pole corresponded to $6.035 \mathrm{~m}$ on the level indicator.

When measuring the discharge, the maximum water level of the lake reached 3,543.236 $\mathrm{m}$ a.s.l., however, the highest level recorded by the level indicator was $104 \mathrm{~mm}$ higher (3,543.340 m on July 6, 2008 at 3:30 p.m.). When creating the rating curve, it was therefore necessary to extrapolate flow rates for the highest water levels (above 3,543.236 $\mathrm{m}$ a.s.l.).

The annual cycle of lake level fluctuations was divided into three parts. Water level decline (phase I) was determined from the moment, when the water 


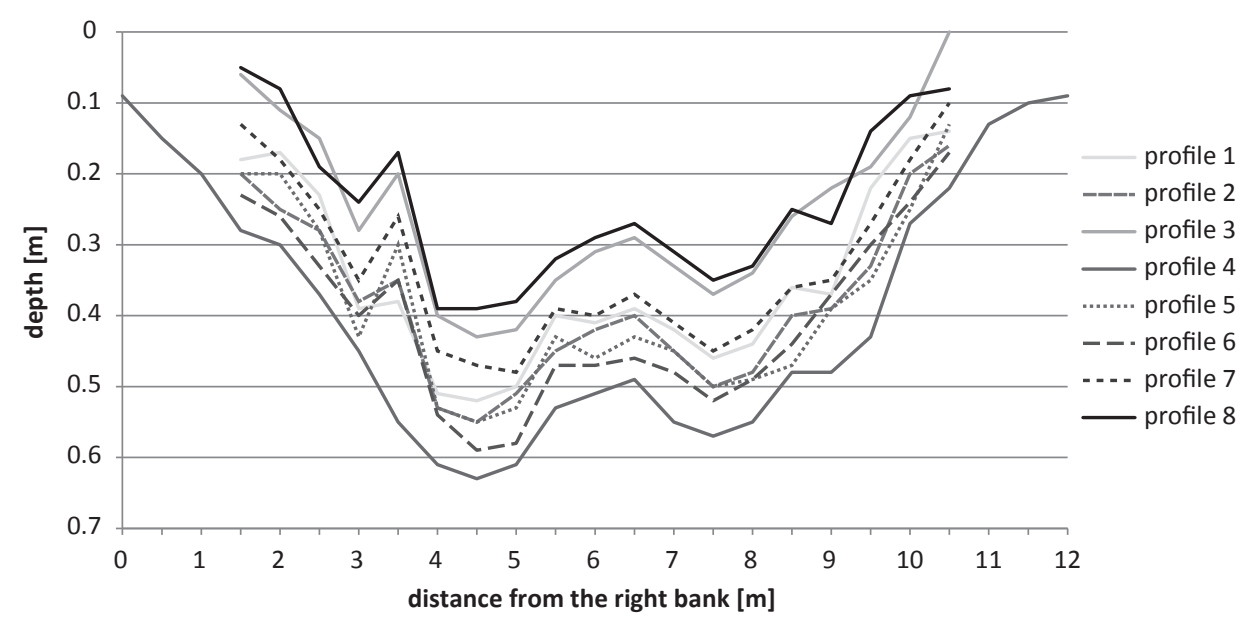

Fig. 4 - Cross section profiles of lake outflow at different water stages. Measurement time: profile 1 - 3.8. 15:30-16:00; profile 2 - 3.8. 17:45-18:05; profile $3-4.8$. 8:00-8:15; profile 4 4.8. 17:20-17:40; profile 5-4.8. 20:10-20:35; profile 6 - 5.8. 10:10-10:30; profile 7 - 5.8. 13:50-14:10; profile $8-5.8$. 15:00-15:15.

level was only declining to the minimum of the given cycle. This phase was additionally divided into two parts - in the first part, the level was declining rapidly, in the second one the decline was significantly slower. The boundary between the two parts was determined visually from the graph of the annual variation to November 6 (this day is included in the first part of the decline). When the minimum water level is reached (stage 1), the filling phase begins (phase II), which continues until the moment when the water level first begins to decline after the restoration of the surface outflow from the lake (stage 2). After the lake basin is filled with meltwater from snow and the glacier, the stabilization phase occurs (phase III) during which the water level fluctuates around an altitude of approximately $3,543 \mathrm{~m}$ and shows a daily amplitude of as much as $0.34 \mathrm{~m}$.

There are multiple inflows to the lake, but they are very difficult to measure and a significant part of water also flows into the lake through subsurface channels. The inflow was therefore derived from the change in water level, volume of surface outflow and an approximate calculation of the volume of subsurface outflow. The arithmetic mean of the values of the decline rate in the first phase of all monitored years was calculated to determine the approximate subsurface outflow in the stabilization phase. During filling of the lake, the arithmetic mean of the second part of the decline was used up to the altitude of $3,541 \mathrm{~m}$ a.s.l. and from this level the same value as during stabilization was used. 


\section{Results}

\subsection{Lake Level Fluctuations}

The annual cycle of lake level fluctuations shows a considerable regularity within a monitored period of five consecutive cycles as demonstrated in Figure 5. Each curve can be divided into three parts: I. level decline, II. filling, and III. stabilization.

The longest lasting is the first part (about 7 months) during which the lake water level declines due to outflow through subsurface channels. There is a significant drop in temperature in September and thus the volume of meltwater flowing into the lake from the glacier decreases. Around mid-September, the lake level declines to the point, from which the lake has no surface outflow. This occurs at a lake level altitude of 3,542.606 m. From this level, the lake is drained only through subsurface channels, the capacity of which remained relatively unchanged throughout the monitored period. The convex shape of the curves shows that some outflow routes are uncovered with the water level decline and therefore the rate of water level decline decreases (Table 1).

The second phase - filling of the lake - begins after the lowest water level is reached. The minimum water level varies from year to year - the largest difference between the measured lowest water levels in individual years was $288 \mathrm{~mm}$ (2008: 3,540.025 m a.s.l.; 2010: 3,540.313 $\mathrm{m}$ a.s.l.). Reaching of the minimum water level is affected by the capacity of drainage channels, available water input from snowmelt in spring, the volume of base flow, but also by relatively high air temperatures in September (or October) that could delay the onset of the water level decline and thereby shorten this period. The beginning, course and time of filling vary considerably between the monitored years (Table 2). The earliest beginning of the filling occurred in 2012 (April 17) and the latest filling began May 3, 2009. The entire filling process depends only on the course of air temperature and radiation, which affects the intensity of snow melting.

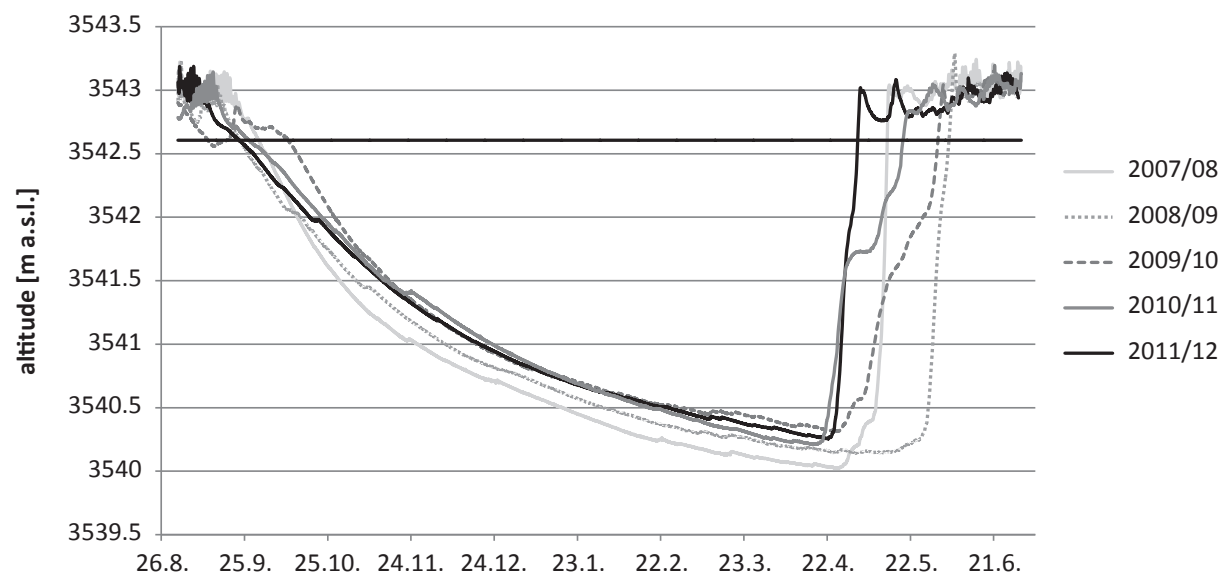

Fig. 5 - Annual course of water level fluctuation at lake Adygine. Surface outflow altitude marked with a solid black line. 
Tab. 1 - Parameters of lake water level decline

\begin{tabular}{|c|c|c|c|c|c|c|}
\hline \multirow[t]{2}{*}{ Year } & \multicolumn{3}{|c|}{$1^{\text {st }}$ part of decline (until $6^{\text {th }}$ Nov) } & \multicolumn{3}{|c|}{$2^{\text {nd }}$ part of decline (since $7^{\text {th }}$ Nov) } \\
\hline & $\begin{array}{l}\text { Volume }\left(\mathrm{m}^{3}\right) / \text { water } \\
\text { level }(\mathrm{cm}) \text { change }\end{array}$ & $\begin{array}{l}\text { Time } \\
\text { (days) }\end{array}$ & $\begin{array}{l}\text { Velocity }(1 / \mathrm{s}) / \\
\text { (cm/day) }\end{array}$ & $\begin{array}{l}\text { Volume }\left(\mathrm{m}^{3}\right) / \text { water } \\
\text { level }(\mathrm{cm}) \text { change }\end{array}$ & $\begin{array}{l}\text { Time } \\
\text { (days) }\end{array}$ & $\begin{array}{l}\text { Velocity }(\mathrm{l} / \mathrm{s}) / \\
(\mathrm{cm} / \text { day })\end{array}$ \\
\hline $2007 / 08$ & $31,457 / 131.6$ & 39 & $9.34 / 3.4$ & $26,854 / 126.5$ & 172 & $1.81 / 0.74$ \\
\hline 2008/09 & $27,691 / 115.0$ & 45 & $7.12 / 2.6$ & $28,230 / 131.2$ & 179 & $1.83 / 0.73$ \\
\hline $2009 / 10$ & $21,958 / 90.2$ & 28 & $9.07 / 3.2$ & $30,520 / 139.1$ & 172 & $2.05 / 0.81$ \\
\hline 2010/11 & $23,659 / 97.5$ & 46 & $5.95 / 2.1$ & $30,007 / 137.6$ & 169 & $2.06 / 0.81$ \\
\hline $2011 / 12$ & $23,054 / 94.9$ & 42 & $6.35 / 2.3$ & $31,529 / 144.7$ & 163 & $2.23 / 0.89$ \\
\hline
\end{tabular}

Tab. 2 - Parameters of lake filling

\begin{tabular}{|rrrrrrrrrr|}
\hline Year & $\begin{array}{c}\text { Begin- } \\
\text { ning }\end{array}$ & $\begin{array}{c}\text { Stage 1 } \\
(\mathrm{m} \text { a.s.l. })\end{array}$ & End & $\begin{array}{c}\text { Stage 2 } \\
(\mathrm{m} \text { a.s.l. })\end{array}$ & $\begin{array}{c}\text { Time } \\
(\text { days })\end{array}$ & $\begin{array}{c}\text { Volume 1 } \\
\left(\mathrm{m}^{3}\right)\end{array}$ & $\begin{array}{c}\text { Volume 2 } \\
\left(\mathrm{m}^{3}\right)\end{array}$ & $\begin{array}{c}\text { Volume } \\
\text { change } \\
\left(\mathrm{m}^{3}\right)\end{array}$ & $\begin{array}{c}\text { Filling } \\
\text { velocity } \\
(\mathrm{l} / \mathrm{s})\end{array}$ \\
\hline 2008 & 26.4. & $3,540.025$ & 14.5. & $3,543.041$ & 18 & 137,698 & 207,076 & 69,378 & 44.6 \\
2009 & 3.5. & $3,540.144$ & 8.6. & $3,543.292$ & 36 & 140,088 & 213,902 & 73,814 & 23.7 \\
2010 & 26.4. & $3,540.313$ & 9.6. & $3,542.986$ & 44 & 143,531 & 205,791 & 62,260 & 16.4 \\
2011 & 23.4. & $3,540.255$ & 5.5. & $3,543.020$ & 12 & 142,343 & 206,682 & 64,339 & 62.0 \\
2012 & 17.4. & $3,540.210$ & 21.5. & $3,542.839$ & 34 & 141,426 & 201,969 & 60,543 & 20.6 \\
\hline
\end{tabular}

The third phase of the cycle of the annual evolution of lake water level is stabilization and daily fluctuations. The longest period of stabilization was recorded in 2011, when the lake was filled quite early due to increased temperatures in late April and the phase lasted for 133 days. In contrast, the shortest time of summer water level fluctuation was in 2010, when the water level began to fluctuate on June 10 and the water level declined already on September 12 due to rather low temperatures in early September. Overall, this phase lasted only 93 days, which is $70 \%$ of the longest period.

The diurnal cycle of lake level fluctuation depends on the diurnal temperature variability that affects the rate of snow and glacier melting. The highest water level is usually recorded several hours after the sun culmination, i.e. around 3-5 p.m. After that, the water level gradually declines and reaches its minimum in the morning, around 8-10 a.m., which is related to the delayed inflow into the lake.

A very similar pattern of daily water level fluctuations in the ablation season (Fig. 6) was identified in the monitored period. The amplitude of the water level during the day ranges within several tens of millimetres in first weeks. The daily water level fluctuations increase gradually with increasing air temperature and radiation intensity, while maximum values were identified in August, usually in its second half. A maximum value of about $300 \mathrm{~mm}$ was identified in each of the monitored period; however, in 2009 the water level fluctuation did not exceed $205 \mathrm{~mm}$. The daily fluctuation declines relatively quickly until it stops completely and is replaced again by a phase of decline.

An interesting phenomenon typical for glacial hydrological regime is a runoff delay, which is variable throughout the ablation season. A considerable reduction of the runoff delay is observed at the beginning of the ablation 

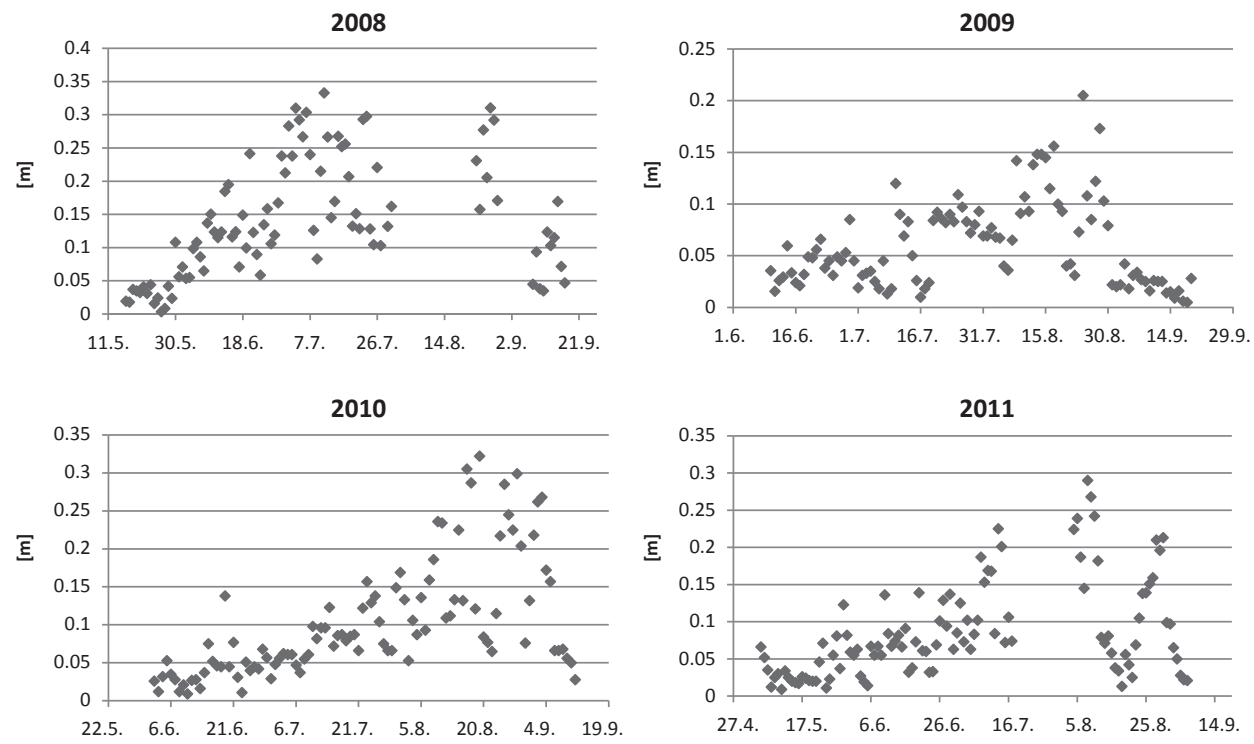

Fig. 6 - Water level fluctuation in ablation seasons of 2008-2011

season. It is attributed to the gradual melting of the snow cover, which slows down the runoff. At the peak of summer, the glacier responds to the increase in air temperature more quickly. The delay period thus decreases which is enhanced by a drainage system created and deepened during the ablation period and it extends up the glacier so the transport of meltwater becomes more effective (Hubbard, Glasser 2005). Beitlerová (2010) monitored the runoff delay for the ablation season of 2008 (Fig. 7). The first 10 days were of the largest delay, specifically 10-12 hours, followed by a period with a delay of 4-9 hours and at the peak of summer with a fully evolved diurnal cycle the delay reached only around 4 hours and even significantly lower values ( 1 hour) occurred. In late August, delays of $2-6$ hours were detected (Beitlerová 2010).

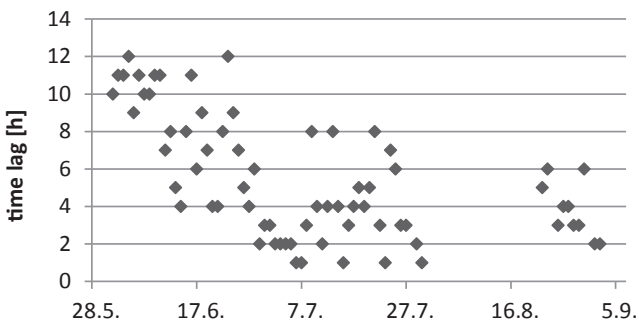

Fig. 7 - Runoff delay development in ablation season of 2008 (Beitlerová 2010)

\subsection{Surface Outflow}

The surface outflow from Adygine Lake runs over the lowest point of the dam starting from the water level reaching the altitude of $3,542.606 \mathrm{~m}$. The discharge derived from the rating curve depends mainly on the air temperature at the given location. Due to rapid response of the glacier to increased solar 

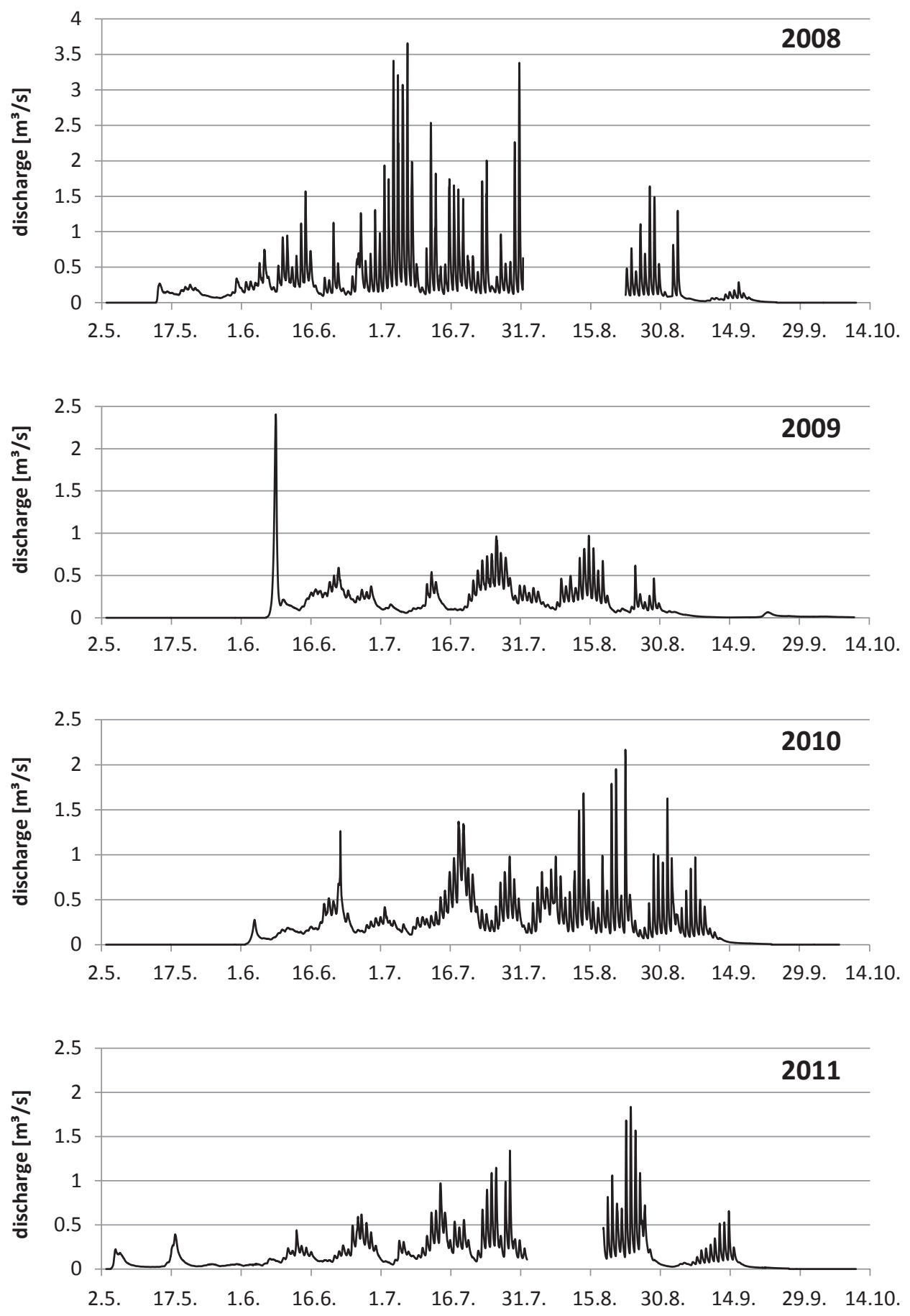

Fig. 8 - Discharge at lake Adygine outflow during ablation seasons of 2008-2011 


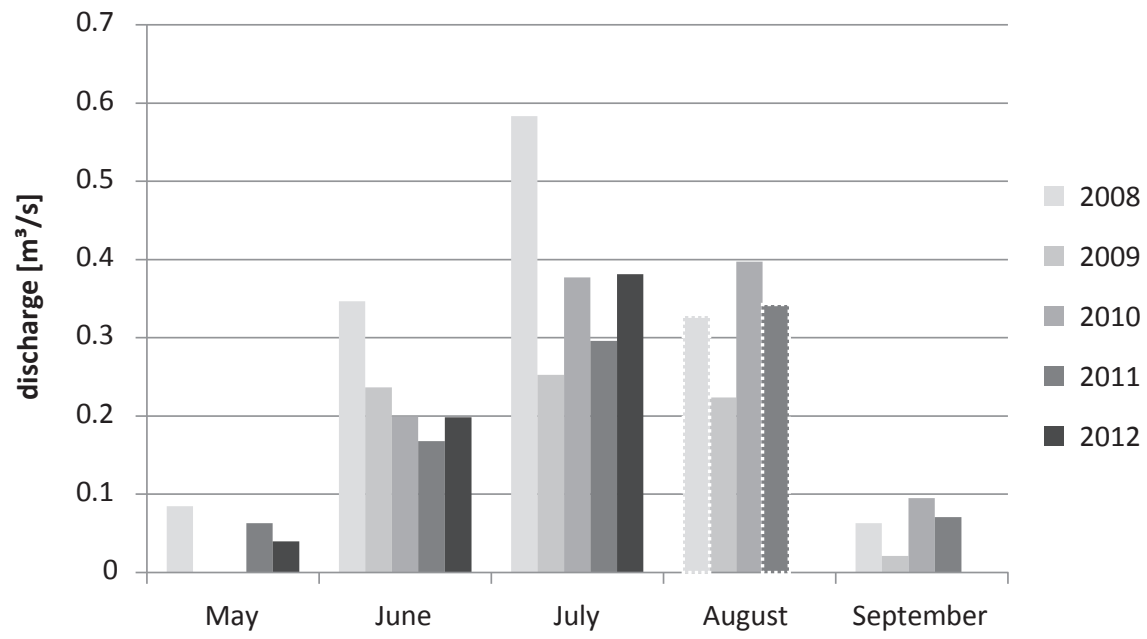

Fig. 9 - Mean monthly discharge at lake Adygine outflow, 2008-2012; white dashed outline noting incomplete data

radiation and air temperature, the lake shows a significant diurnal discharge regime at the lake outflow.

It is apparent from Figure 8 that the course of the ablation season significantly varies between the monitored years. The year 2008 was above-average in terms of water discharge at the outflow. Surface outflow was recorded relatively early and the high melting intensity of glacier ice showed in early July due to high air temperatures. A significant daily regime with maximum flow rates of over $3 \mathrm{~m}^{3} . \mathrm{s}^{-1}$ evolved and lasted with short breaks at least throughout July. In contrast, rather below-average flow rates were recorded in the following year. There was a very rapid increase in water level and thus also the discharge right at the beginning of the ablation season. It is likely that it was caused by intense snow melting over a large area. However, the discharge decreased and during the summer it did not exceed $1 \mathrm{~m}^{3} \cdot \mathrm{s}^{-1}$. The diurnal regime evolved only in a limited extent. In the following two years (2010,2011), summer flow rates were without any abnormalities. As the ablation season progressed, the diurnal regime evolved and flow rates reached the highest values in the second half of August.

The year of 2008 has high values of average flow rates for individual months (Fig. 9). Average monthly flow rates for 2009 are rather low and the similarity of values for June, July and August is unusual.

\subsection{Balance of Lake Inflow and Outflow}

The cumulative volume of surface outflow from Adygine Lake for individual monitored years 2008-2012 is shown in Figure 10. Differences in the initiation date, the course of outflow accumulation and its total volume for the entire ablation season are clearly noticeable. 


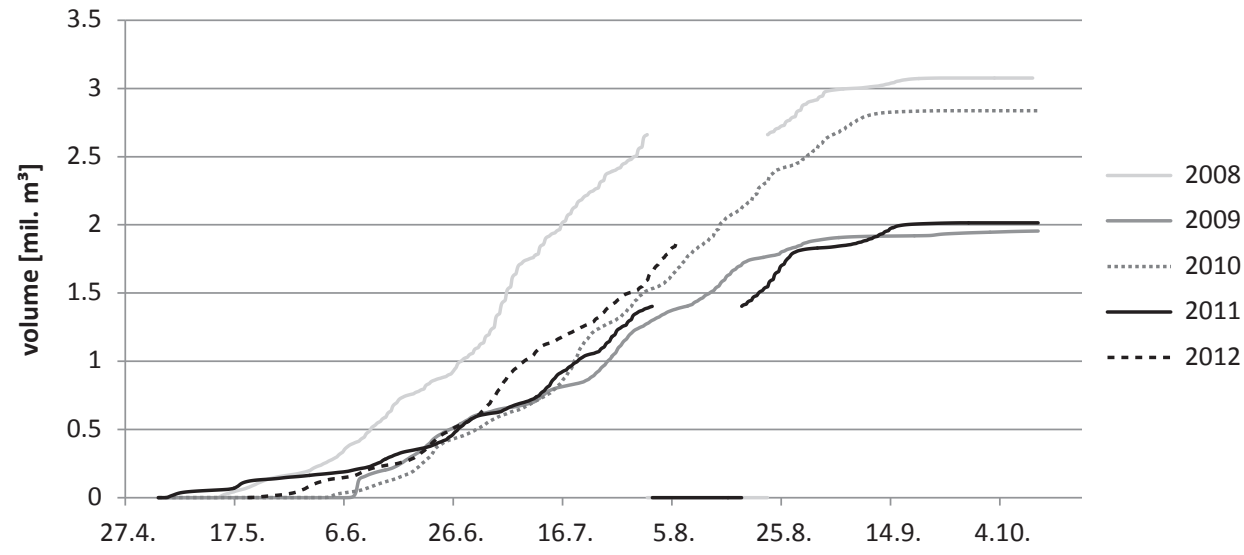

Fig. 10 - Cumulative volume of surface runoff for years 2008-2012

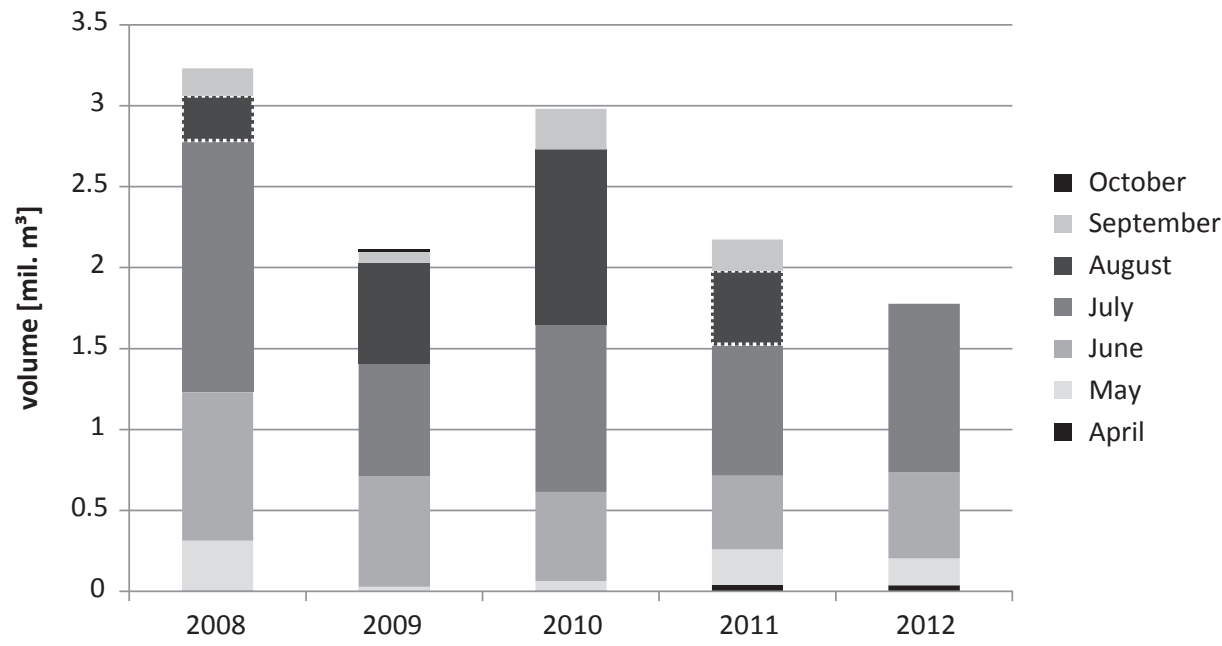

Fig. 11 - Volume of lake inflow for individual months of 2008-2012; white dashed outline noting incomplete data

Despite the different date of outflow initiation in individual years, the cumulative volume was around $500,000 \mathrm{~m}^{3}$ on June 26 for most of the years. The only exception was the year 2008 when at this time the accumulated volume was nearly double. The total outflow volumes for individual years are significantly different. The most water drained from the lake in 2008 - it was 3.1 million $\mathrm{m}^{3}$ for the measured period. Due to a lack of data (see 4.1. Data), however, this value does not correspond to the total volume for the entire ablation season. The actual volume of outflow water drained from the lake is estimated at 3.5-3.8 million $\mathrm{m}^{3}$. The least amount of water drained from the lake through surface channel in 2009 , specifically 1.9 million $\mathrm{m}^{3}$. 
For a complete description of the hydrological regime of Adygine Lake, it is necessary to add information on the inflow. The different height of the bars in the graph (Fig. 11) points to seasonal climate variability in the monitored area. The graph shows the distribution of inflowing water in individual months April to October. Water started to flow into the lake (in a recordable amount) already in April during the last two monitored years (2011, 2012). In May, a significant inflow of water was detected in 2008 (nearly $309,000 \mathrm{~m}^{3}$ ), however, in 2009 and 2010 the inflow was rather low for this month $\left(27,000\right.$ and $59,000 \mathrm{~m}^{3}$, respectively). There are no such major differences for June inflow volumes of individual years. June 2008 dominates with nearly $920,000 \mathrm{~m}^{3}$ and June of the otherwise cold year 2009 was also relatively rich in water. July and August are most significant in terms of inflow. During these months $>2$ million $\mathrm{m}^{3}$ of water flows into the lake, which was the case in 2010 and probably also in 2008. Air temperatures in September often drop below $0^{\circ} \mathrm{C}$ and melting is thus limited reducing the inflow significantly. Relatively high temperatures in the first half of September 2010 caused that about $254,000 \mathrm{~m}^{3}$ of water flowed into the lake in this month. In 2009 , it was only $72,000 \mathrm{~m}^{3}$, however, the air temperature did not drop in the second half of September and therefore inflow into the lake was recorded even in early October, which is rather unusual.

\section{Discussion}

\subsection{Uncertainties of Measurements and Data Processing}

It is very difficult to measure precipitation under the given conditions (see 4.2. Methods) at the studied area. Particularly solid precipitation is difficult to capture, as it is blown out of the rain gauge, which is not heated. There is not enough sunshine for a solar panel, which could provide heating of the rain gauge. The rain gauge in the upper meteorological station captures about $300-500 \mathrm{~mm}$ of precipitation per year. Given the altitude and the northern aspect of the site, the estimated values are around 1,200 mm (Černý et al. 2010). Aizen et al. (1996) mention, that there is a single precipitation maximum in the mountainous areas of the Kyrgyz range, specifically in May - July. At altitudes where the Adygine complex is situated, i.e. above 3,400 m a.s.l., precipitation in this time period represents up to $72 \%$ of the annual precipitation and about $65 \%$ of the precipitation falls down in the form of snow (Aizen, Aizen, Melack 1996). Figure 12 shows daily precipitation for three months of 2012 with the highest precipitation - May: $58.4 \mathrm{~mm}$, June: $114 \mathrm{~mm}$, July: $79.9 \mathrm{~mm}$ (total of $252.3 \mathrm{~mm}$ ). It is evident that the measured values do not correspond with the expected precipitation in this area and substantial part of precipitation is not detected by the measuring device. The meteorological stations also have incomplete data series due to technical problems. Therefore, the precipitation data could be used only in a limited way.

Other inaccuracies can occur during processing of the measured data. Depth of a certain spot was adjusted within two profiles when calculating the flow rates. After this adjustment, a rating curve with a higher reliability value was 


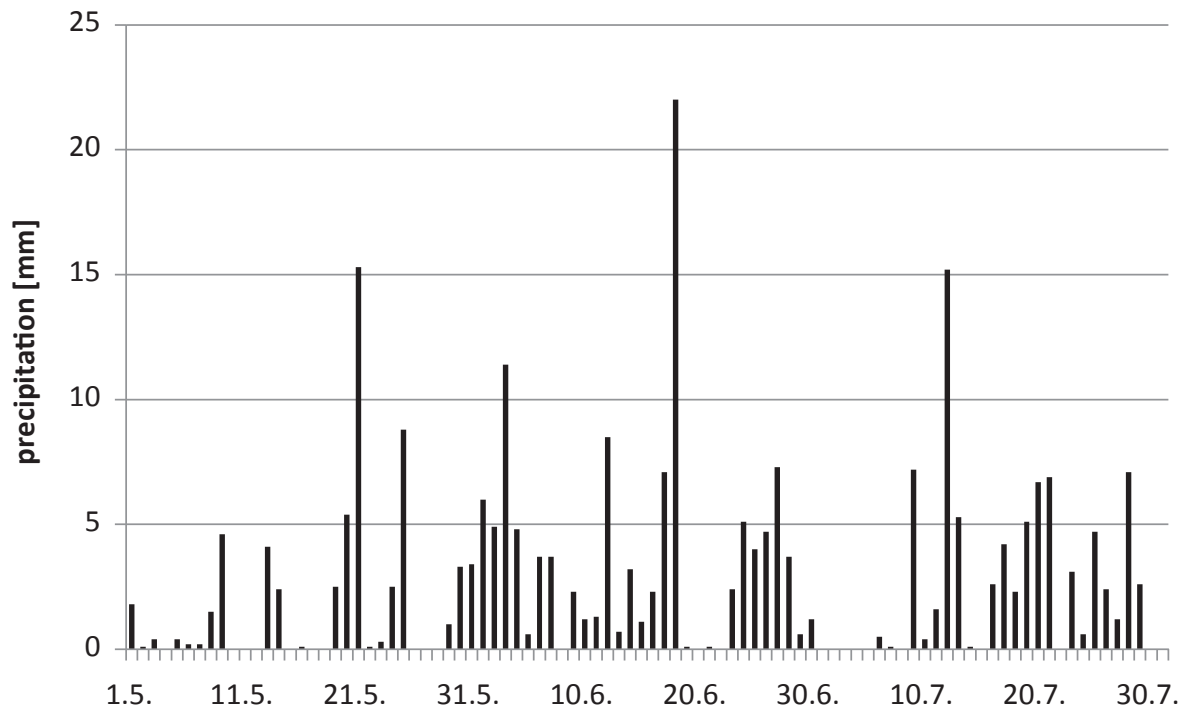

Fig. 12 - Daily amount of precipitation for May-June period of 2012, upper meteorological station

fitted through the points ( $\mathrm{x}$ - discharge, $\mathrm{y}$ - water level). Flow rates for water levels of the entire monitored period were calculated using the equation of this curve. Generalization is necessary here, but the question is whether the number of measurements (eight) is sufficient. Except for one case, all points were located close to the curve. The reliability value of 0.9914 is satisfactory in this case. Nevertheless, it is necessary to mention that greater errors could probably occur here as the values of calculated flow rates are used for further calculations (e.g. outflow volume).

The calculation of the inflow to the lake is indirect. It was estimated on the basis of a change in the volume of the lake, surface and subsurface outflow. Uncertainties associated with the calculation of the volume of the lake and surface outflow have been outlined above. The exact volume of subsurface runoff is not known, it is estimated according to the water level decline without surface outflow. However, the lake is constantly supplied from the base flow from the glacier and therefore the subsurface runoff from the lake will be actually slightly higher. In addition, the volume of runoff through subsurface channels varies during the season and even between individual years as some of the channels could be closed and new ones opened. Complicated system of subsurface channels and cracks was confirmed by geophysical measurements in 2008 (Černý et al. 2010). This phenomenon was observed by the research team at similar lake sites in Kyrgyzstan as well. The arithmetic mean of all monitored years was used to approximate the calculated values to the actual volume of the inflow. 


\subsection{Glacial hydrological regime}

In this study, the hydrological regime of Adygine Lake situated near the glacier front at an altitude of 3,643 m was described. Individual characteristics of the outflow exhibit elements typical for a glacial hydrological regime, which is described in detail in studies by Jobard and Dzikowski (2006), Singh et al. (2006) or Han et al. (2013).

The flow rate in the ablation season is considerably variable and depends mainly on air temperature and radiation. Starting with rather lower values, discharge at the outflow from Lake Adygine peaks in mid-summer (mostly in August). Similar discharge evolution during ablation season was observed also by Fountain (1985) in North Cascade Mts, USA, or by Jobard and Dzikowski (2006) in French Alps.

Swift et al. (2005) point out the fact that in spring a large part of short-wave radiation is reflected due to high albedo of snow and therefore melting occurs after an increase in air temperature. Therefore, the influence of radiation is limited here. On the other hand, relatively lower albedo of exposed glacier increases the importance of radiation, which accelerates melting (the ice-albedo positive feedback).

The influence of precipitation on flow rate is probably more complex. Some studies have considered it to be minimal, e.g. Han et al. (2013) did not find any significant dependence of flow rate on precipitation. In contrast, Fujita (2008) describes summer precipitation that can accelerate melting and increase flow rate in a single occurrence. Unfortunately, we don't have data on state of precipitation that fall on the study area. However, as maximum precipitation occurs in summer, it probably has certain influence on the melting process.

The onset and end of the ablation season depends on the latitude, but also on basin aspect and climatic conditions (air temperature, precipitation) of a study site. While at the study area and elsewhere in the northern Tien Shan (Han et al. 2013) or the Swiss Alps (Swift et al. 2005) the temperatures drop below $0{ }^{\circ} \mathrm{C}$ already during September, in the Himalayas at $31^{\circ} \mathrm{N}$ the ablation season usually does not end before the turn of October and November (Singh et al. 2006). The complex Adygine is north-oriented and a significant reduction in solar energy input in September causes rather rapid decline of lake water level.

Well-pronounced daily water level fluctuation was noticed in July and August at the study site. By this time most snow is already melted and the main source of meltwater is glacier ice. The proportion of meltwater from snow, firn and glacier ice in discharge is described by Jansson, Hock, Schneider (2003), who has observed changes in daily regime as well. A study by Hock (1998) also confirms that a more distinct daily regime develops after melting of most snow and the flow rate increases after uncovering of larger area of the glacier. The development of discharge daily amplitude is similarly described by others as well (Jobard, Dzikowski 2006; Singh et al. 2006; Han et al. 2013). As the melting season at Adygine progresses, there are greater differences between the daily minimum and maximum discharge at lake's outflow (Fig. 13). Very similar evolution of daily discharge amplitude (Fig. 14) was monitored in the Alps on a stream draining Gornergletscher (Elliston 1973). 


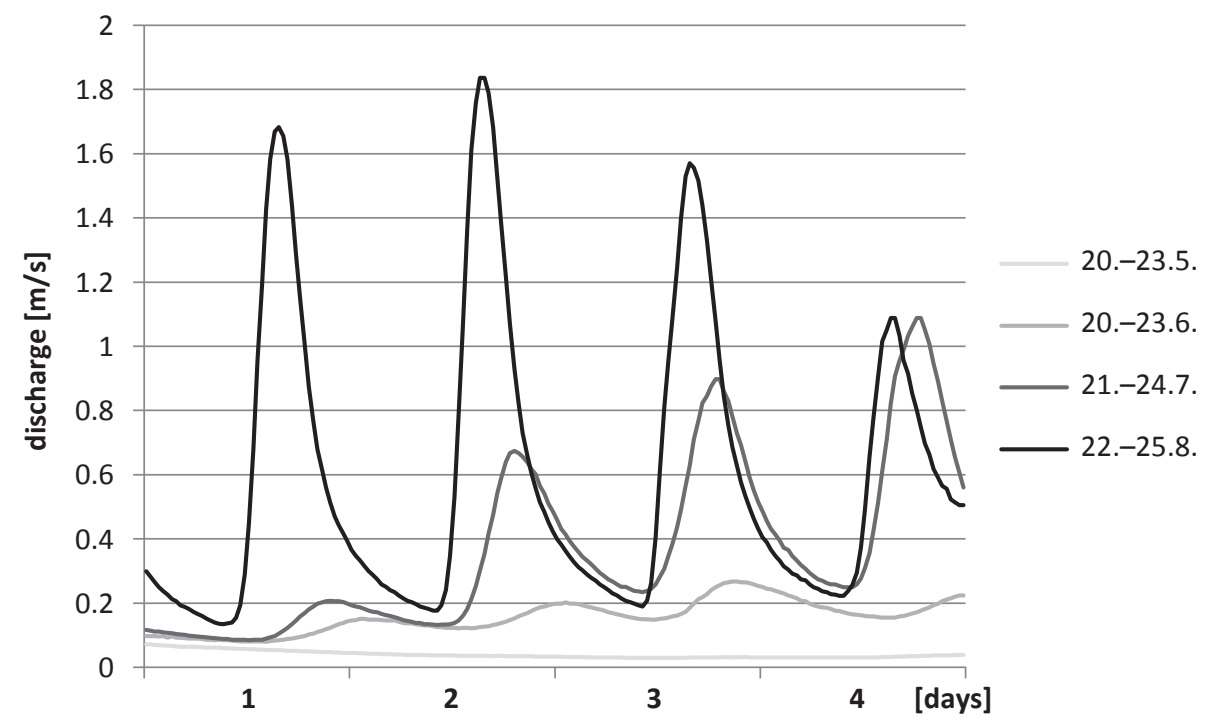

Fig. 13 - Daily discharge amplitude evolution at lake Adygine outflow

Han et al. (2013) focus on the differences between discharges measured during the day and night. It is affected by cloud cover during the day - "a clearweather day" results in larger differences than an overcast day.

Runoff delay is another feature of glacial hydrological regime observed at Lake Adygine. Richards et al. (1996) also examined the development of runoff delay in the ablation season finding similar tendency to time lag decline as in this study. According to Jobard and Dzikowski (2006) snow cover significantly slows down the runoff, however, when it's melted, there is a rapid decrease in the lag time mainly due to gradually developing effective network of drainage channels (Hubbard, Glasser 2005; Singh et al. 2006). That is why the diurnal maximum discharge value occurs earlier in peak summer than at the beginning of the ablation season (Fig. 13, Fig. 14). Data presented by Jobard and Dzikowski (2006) contain similar values of runoff delay to those noticed at Lake Adygine: in early June values of 8-10 hours, continued by time lag decline till 2-4 hours in mid-July and then time lag stabilization for the rest of the season. Han et al. (2013) also mention in this context the influence of "consecutive clear-weather days" which may further reduce the delay. In the middle of an ablation season, radiation plays a major role - its maximum occurs even several hours before the maximum air temperature is reached and therefore the runoff delay gets shorter.

\section{Conclusions}

The hydrological regime of Adygine Lake shows features typical of the regime of glacial lakes. Changes in the water level have annual periodicity and a daily regime develops during the ablation season. Water level fluctuations during 
the year can be divided into three phases: decline, filling and fluctuations. The longest-lasting phase is the first mentioned one, when the water level usually declines from mid-September with a slowing tendency until April/May. The filling phase is highly variable in terms of timing and duration. The shortest recorded time was 12 days (2011), the longest up to 44 days (2010). It is followed by a phase of fluctuations during which a daily regime develops. The fluctuation of the lake level during the day is affected by air temperature and solar radiation intensity and as the ablation season progresses, the fluctuation increases due to more intensive melting on the glacier surface. The maximum usually occurs around mid-August. This is associated with shortening of the runoff delay during the summer due to developing drainage system of the glacier.

Adygine Lake has a relatively regular cycle of fluctuations. No major changes in the hydrological regime were recorded in the monitored period. Its changes depend on meteorological conditions in individual years.

Subsurface drainage channels divert water from the lake through the dam and thereby supplement the surface outflow. Their capacity varies between years. However, not even here a tendency towards increase or decrease in the drainage capacity was observed. The slowing decline of the lake water level during winter indicates the approximate distribution of the drainage channels. However, their precise distribution and reasons for changes in their capacity should be subject to further research. Subsurface outflow may lower the dam stability and finding out more information about the functioning and development of these drainage channels could help better identify the risk of an outburst of Adygine Lake.

\section{References:}

ADYSHEV, M.M. ed. (1987): Atlas Kirgizskoj CCP. GUGK SSSR, Moscow, 157 pp.

AGETA, Y., IWATA, S., YABUKI, H., NAITO, N., SAKAI, A., NARAMA, C., KARMA, T. (2000): Expansion of glacier lakes in recent decades in the Bhutan Himalayas. IAHS Publication, pp. 165-176. 
AIZEN, V.B., AIZEN, E.M. (1994): Features of regime and mass exchange of some glaciers on central Asia periphery. Bulletin of Glacier Research, 12, pp. 9-24.

AIZEN, V.B., AIZEN, E.M., MELACK, J. (1995): Climate, snow cover, glaciers, and runoff in the Tien-Shan, Central Asia. Water Resources Bulletin, 31, No. 6, pp. 1113-1129.

AIZEN, V.B., AIZEN, E.M., MELACK, J.M. (1996): Precipitation, melt and runoff in the northern Tien Shan. Journal of Hydrology, 186, pp. 229-251.

AIZEN, V.B., AIZEN, E.M., MELACK, J.M., DOZIER, J. (1997): Climate and hydrologic changes in the Tien Shan, central Asia. Journal of Climate, 10, pp. 1393-1404.

AIZEN, V.B., KUZMICHENOK, V.A., SURAZAKOV, A.B., AIZEN, E.M. (2006): Glacier changes in the central and northern Tien Shan during the last 140 years based on surface and remote-sensing data. Annals of Glaciology, 43, pp. 202-213.

BATES, B.C., KUNDZEWICZ, Z.W., WU, S., PALUTIKOF, J.P., eds. (2008): Climate Change and Water. Technical Paper of the Intergovernmental Panel on Climate Change, IPCC Secretariat, Geneva, 210 pp.

BEITLEROVÁ, H. (2010): Ledovcový hydrologický režim, případová studie jezera Adygine (Ťan Šan, Kyrgyzstán). Bc. Thesis. Univerzita Karlova v Praze, Př́rodovědecká fakulta, katedra fyzické geografie a geoekologie, Praha, $75 \mathrm{pp}$.

BENISTON, M., DIAZ, H.F., BRADLEY, R.S. (1997): Climatic change at high elevation sites: an overview. Climatic Change, 36, No. 3-4, pp. 233-251.

BENN, D.I., EVANS, D.J.A. (2010): Glaciers and Glaciation. $2^{\text {nd }}$ ed., Hodder Education, London, $816 \mathrm{pp}$.

CLAGUE, J.J., EVANS, S.G. (2000): A review of catastrophic drainage of moraine-dammed lakes in British Columbia. Quaternary Science Reviews,19, No. 17, pp. 1763-1783.

COLLINS, D.N. (1998): Rainfall-inducted high-magnitude runoff events in highly-glacialized Alpine basins. In: Hydrology, Water Resources and Ecology in Headwaters. Proceedings of the HeadWater'98 Conference, Merano, Italy, 248, pp. 69-78.

ČERNÝ, M., ŠOBR, M., ENGEL, Z., KOCUM, J., HRDINKA, T., JANSKÝ, B., HŮLKA, L., ŽÁČEK, M., JEROCHIN, S. A., ERMANGAEV, B., ZAGINAEV, V.V., KUZNECOV, B.A., ZAJAGIN, D. (2010): Analýza rizik a omezení důsledků protržení hrází vysokohorských jezer. Závěrečná zpráva projektu rozvojové spolupráce mezi Českou a Kyrgyzskou republikou RP9/2007, GEOMIN družstvo, Jihlava, 2 parts, 20 suppl., 242 pp.

ČESÁK, J., ŠOBR, M. (2005): Metody batymetrického mapování českých jezer. Geografie, 109, No. 3, pp. 141-151.

DVOŘÁK, V., HLADNÝ, J., KAŠPÁREK, L. (1997): Climate change hydrology and water resources impact and adaptation for selected river basins in the Czech Republic. Climatic Change, 36, No. 1-2, pp. 93-106.

DYURGEROV, M. (2003): Mountain and subpolar glaciers show an increase in sensitivity to climate warming and intensification of the water cycle. Journal of Hydrology, 282, pp. $164-176$.

ELLISTON, G.R. (1973): Water movement through the Gornergletscher. IASH Publ, 95, pp. 79-84.

FOUNTAIN, A.G. (1985): The effect of glaciers on streamflow variations. Water Resources Research, 21, No. 4, pp. 579-586.

FUJITA, K. (2008): Influence of precipitation seasonality on glacier mass balance and its sensitivity to climate change. Annals of Glaciology, 48, pp. 88-92.

GAO, X., YE, B., ZHANG, S., QIAO, C., ZHANG, X. (2010): Glacier runoff variation and its influence on river runoff during 1961-2006 in the Tarim River basin, China. Science China Earth Sciences, 53, No. 6, pp. 880-891.

HAGG, W., BRAUN, L.N., KUHN, M., NESGAARD, T.I. (2007): Modelling of hydrological response to climate change in glacierized Central Asian catchments. Journal of Hydrology, 332, pp. 40-53.

HAN, T., GAO, M., YE, B., JIAO, K. (2013): Characteristics of melt water discharge in the Glacier No. 1 basin, headwater of Urumqi River. Journal of Hydrology, 489, pp. 180-188.

HOCK, R. (1998): Modelling of glacier melt and discharge. PhD dissertation, Department of Geography. ETH, Zürich, Switzerland. Zürcher Geographische Schriften, 70, 126 pp. 
HUBBARD, B., GLASSER, N. (2005): Field Techniques in Glaciology and Glacial Geomorphology. John Wiley and Sons Ltd., Chichester, England, 400 pp.

JANSKY, B. ŠOBR, M., YEROKHIN, S. (2006): Typology of high mountain lakes of Kyrgyzstan with regard to the risk of their rupture. Limnological Review, 6, pp. 135-140.

JANSKÝ, B., ŠOBR, M., ENGEL, Z. (2010): Outburst flood hazard: Case studies from the Tien-Shan Mountains, Kyrgyzstan. Limnologica, 40, pp. 358-364.

JANSKÝ, B., ENGEL, Z., KOCUM, J., ŠEFRNA, L., ČESÁK, J. (2011): The Amazon River headstream area in the Cordillera Chila, Peru: hydrographical, hydrological and glaciological conditions. Hydrological Sciences Journal, 56, No. 1, pp. 138-151.

JANSSON, P., HOCK, R., SCHNEIDER, T. (2003): The concept of glacier storage: a review. Journal of Hydrology, 282, pp. 116-129.

JOBARD, S., DZIKOWSKI, M. (2006): Evolution of glacial flow and drainage during the ablation season. Journal of Hydrology, 330, pp. 663-671.

KATTELMANN, R. (2003): Glacial lake outburst floods in the Nepal Himalaya: a manageable hazard? Natural Hazards, 28, No. 1, pp. 145-154.

KOPPES, M., GILLESPIE, A.R., BURKE, R.M., THOMPSON, S.C., STONE, J. (2008): Late Quaternary glaciation in the Kyrgyz Tien Shan. Quaternary Science Reviews, 27, pp. 846-866.

LI, Z. Q., SHEN, Y.P., WANG, F.T., LI, H.L., DONG, Z.W., WANG, W.B., WANG, L. (2007). Response of glacier melting to climate change-take Urumqi Glacier No. 1 as an example. Journal of Glaciology and Geocryology, 29, pp. 333-341.

MIDDELKOOP, H., DAAMEN, K., GELLENS, D., GRABS, W., KWADIJK, J.C.J., LANG, H., PARMET, B.W.A.H., SCHÄDLER, B., SCHULLA, J., WILKE, K. (2001): Impact of climate change on hydrological regimes and water resources management in the Rhine basin. Climatic change, 49, No. 1-2, pp. 105-128.

NIJSSEN, B., O>DONNELL, G.M., HAMLET, A.F., LETTENMAIER, D.P. (2001): Hydrologic sensitivity of global rivers to climate change. Climatic change, 50, No. 1-2, pp. 143-175.

NYE, J.F. (1973): Water at the bed of a glacier. Symposium on the Hydrology of Glaciers, Cambridge, September 1969, pp. 189-194 (Publication No. 95 de l'Association Internationale d'Hydrologie Scientifique).

RICHARDS, K.S., SHARP, M., ARNOLD, N., GURNELL, A.M., CLARK, M., TRANTER, M., NIENOW, P., BROWN, G., WILLIS, I., LAWSON, W. (1996): An integrated approach to modelling hydrology and water quality in glacierized catchments. Hydrological Processes, 10, pp. 475-660.

RÖTHLISBERGER, H. (1972): Water pressure in intra- and subglacial channels. Journal of Glaciology, 11, No. 62, pp. 177-203.

RÖTHLISBERGER, H., LANG, H. (1987): Glacial Hydrology. In: Gurnell, A.M., Clark, M.J. (eds.): Glacio-fluvial Sediment Transfer. Wiley, New York, pp. 207-284.

SINGH, P., HARITASHYA, U. K., KUMAR, N., SINGH, Y. (2006): Hydrological characteristics of the Gangotri Glacier, central Himalayas, India. Journal of Hydrology, 327, pp. 55-67.

SINGH, P., SINGH, V.P. (2001): Snow and Glacier Hydrology. Kluwer Academic Publishers, Dordrecht, The Netherlands, $742 \mathrm{pp}$.

SWIFT, D.A., NIENOW, P.W., HOEY, T.B., MAIR, D.W.F. (2005): Seasonal evolution of runoff from Haut Glacier d'Arolla, Switzerland and implications for glacial geomorphic processes. Journal of Hydrology, 309, pp. 133-148.

UNGER-SHAYESTEH, K., VOROGUSHYN, S., FARINOTTI, D., GAFUROV, A., DUETHMANN, D., MANDYCHEV, A., MERZ, B. (2013): What do we know about past changes in the water cycle of Central Asian headwaters? A review. Global and Planetary Change, 110 , pp. 4-25.

ZHOU, Z., JING, Z., ZHAO, S., et al. (2010): Response of Glacier moving speed to climate change - take Urümqi Glacier No. 1 as an example. Journal of Acta Geoscientica Sinica, 31, No. 2, pp. 2237-2244. 


\section{HYDROLOGICKÝ REŽIM JEZERA ADYGINE, TIEN SHAN, KYRGYZSTÁN}

Tání ledovců ve vysokohorských oblastech a s ním související vznik a vývoj jezer je předmětem zájmu mnoha výzkumných týmů působících po celém světě. Ledovcová jezera mohou být velmi nestabilní a ohrožovat tak údolí pod nimi. Zkoumaná lokalita se nachází v Kyrgyzském hřbetu pohoří Tien Shan, asi 40 km jižně od hlavního města Kyrgyzstánu, Biškek. Článek se zabývá rozborem hydrologického režimu největšího jezera lokality, jezera Adygine Horní.

Díky získaným datům $\mathrm{z}$ hladinoměru, meteorologických stanic a měření průtoků na odtoku z jezera bylo vyhodnoceno kolísání hladiny jezera, vývoj průtoku v ablační sezóně a objem přiteklé a odteklé vody. Roční cyklus kolísání byl rozdělen do tř́ fází - pokles hladiny, plnění a ustálení. Během nejdelší fáze poklesu hladiny byl odtok uskutečňován pouze podzemními odtokovými kanály. Díky podrobné batymetrické mapě jezera tak byla vypočtena změna objemu jezera v této fázi, a tak i přibližná kapacita odtokových kanálů. Rychlost poklesu se $\mathrm{v}$ průběhu této fáze snižovala, což naznačuje rozmístění těchto kanálů zejména v horní části jezerní pánve. Fáze plnění představuje poměrně variabilní část celého cyklu. V závislosti na intenzitě slunečního záření a na vzestupu teploty vzduchu se začalo jezero plnit tavnou vodou ze sněhové pokrývky nejdříve 17. 4. (v roce 2012), nejpozději pak 3. 5. (v roce 2009). Nejdéle trvala tato fáze 44 dní (rok 2010, 26. 4.-9. 6.), nejkratší dobu pak v roce 2011, a to pouhých 12 dní (23. 4.-5. 5.). Následuje fáze ustálení, kdy se úroveň hladiny jezera pohybuje kolem nadmořské výšky $3643 \mathrm{~m}$ a je obnoven povrchový odtok. V rámci této fáze byly sledovány dva jevy, a to denní rozkolísanost hladiny a zpoždění odtoku.

Rozkolísanost hladiny během dne je zpočátku nevýrazná, příčinou je tlumivý efekt sněhu, který tavnou vodu částečně zadržuje. Po roztátí sněhové pokrývky je jezero zásobeno vodou z tajícího ledovce a kolísání hladiny se zvětšuje. Největší rozkolísanost byla zaznamenána zpravidla ve druhé polovině srpna, kdy bylo tání díky vysokým teplotám vzduchu a radiaci nejintenzivnější. S prríchodem září se však teploty poměrně rychle snižují a nezřídka se dostávají i pod $0^{\circ} \mathrm{C}$, proto je i denní kolísání hladiny značně shlazeno. Na vývoj zpoždění odtoku má značný vliv opět sněhová pokrývka, která zpočátku odtok značně zpomaluje. Po jejím roztátí se však na povrchu ledovce, uvnitř i pod ním začne vyvíjet drenážní systém odvádějící tavnou vodu z ledovce. Zpoždění odtoku se tak nadále snižuje, nejnižších hodnot pak dosahuje v srpnu.

Průtoky na odtoku z jezera byly vypočteny pomocí konsumpční křivky z údajů o úrovni hladiny. Z nich byl dále vypočten objem vody odteklé povrchovou cestou. Nejvyšší průtoky i celkový objem odteklé vody za ablační sezónu byl zaznamenán v roce 2008, následující rok byl naopak málo vodný. Tomu odpovídaly i vypočtené průměrné měsíční průtoky. Přítoků do jezera je více a jejich změření nebylo možné, proto bylo množství vody odhadnuto ze změny úrovně hladiny, povrchového a podzemního odtoku z jezera. Nejvíce vody přitéká do jezera v červenci a srpnu, celkem za tyto dva měsíce může přitéct i přes 2 mil. m $^{3}$ vody (rok 2010 , nejspíše i 2008).

Průběh kolísání hladiny se mezi jednotlivými roky ve sledovaném období lišil, nebyly však zaznamenány výrazné změny. Poměrně proměnlivá je kapacita podzemních odtokových kanálů. Příčin může být více, opět však nebyl zjištěn stálý posun at již k zvětšení či zmenšení kapacity těchto odtokových cest. Jejich rozmístění a proměnlivá kapacita by měly být podrobeny dalšímu zkoumání.

Obr. 1 - Satelitní snímek zájmové oblasti Adygine, rok 2006. 1 - Adygine Dolní, 2 - Adygine Horní, 3-7 - nová jezera u čela ledovce, M1, M2 - meteostanice. Zdroj: Google Earth.

Obr. 2 - Průměrné měsíční teploty vzduchu (vlevo), meteostanice Ala Archa, $2200 \mathrm{~m} \mathrm{n}$. m., 2002-2008 a průměrné denní a měsíční teploty vzduchu v lokalitě Adygine (vpravo), 3653 m n. m., 2011.

Obr. 3 - Průběh teplot naměřených na horní meteostanici, dolní meteostanici a denní průměry teplot naměřené teplotním čidlem (vlevo) a graf korelace hodnot teploty vzduchu (vpravo) z horní (osa x) a dolní (osa y) meteostanice. 
Obr. 4 - Př́ičné profily výtoku z jezera při různých vodních stavech. Doba měření: profil 1 3. 8. 15:30-16:00; profil 2-3. 8. 17:45-18:05; profil 3-4. 8. 8:00-8:15; profil 4-4. 8 . 17:20-17:40; profil 5 - 4. 8. 20:10-20:35; profil 6 - 5. 8. 10:10-10:30; profil 7 - 5. 8. 13:50-14:10; profil 8 - 5. 8. 15:00-15:15.

Obr. 5 - Roční průběh kolísání hladiny jezera Adygine. Nadmořská výška povrchového odtoku vyznačena plnou černou čarou.

Obr. 6 - Rozkolísanost hladiny v ablační sezóně let 2008-2011.

Obr. 7 - Vývoj zpoždění odtoku v ablační sezóně roku 2008 (podle Beitlerové 2010).

Obr. 8 - Průtok na odtoku z jezera Adygine v průběhu ablační sezóny, 2008-2011.

Obr. 9 - Průměrné měsíční průtoky. Sloupce za srpen 2008 a 2011 jsou ohraničeny čárkovaně kvůli neúplnosti dat.

Obr. 10 -Kumulativní objem povrchového odtoku za roky 2008-2012.

Obr. 11 -Objem přítoku do jezera za jednotlivé měsíce v letech 2008-2012.

Obr. 12 -Denní úhrny srážek za období květen-červenec roku 2012, horní meteostanice.

Obr. 13 -Vývoj denní amplitudy průtoku na odtoku z jezera Adygine.

Obr. 14 - Vývoj denní amplitudy průtoku na toku odvodňující ledovec Gornergletscher, Švýcarsko. Sledovaná období roku 1959: a) 17.-20. 5. b) 14.-17. 6. c) 23.-26. 6. d) 19.-22. 7. Zdroj: Elliston (1973).

Authors' affiliation: Charles University in Prague, Faculty of Science, Dpt. of Department of Physical Geography and Geoecology, Albertov 6, 12843 Praha 2, Czechia; email: falatkok@ natur.cuni.cz,sobr@natur.cuni.cz,kocum1@natur.cuni.cz, bohumir.jansky@natur.cuni.cz.

Initial submission, 17 December 2013; final acceptance 10 October 2014.

\section{Please cite this article as:}

FALÁTKOVÁ, K., ŠOBR, M., KOCUM, J., JANSKÝ, B. (2014): Hydrological regime of Adygine lake, Tien Shan, Kyrgyzstan. Geografie, 119, No. 4, pp. 320-341. 